\title{
Fark Yaratan Uygulamalar Perspektifinden Seyahat Acentelerinde İlişkisel Pazarlama Faaliyetlerini Anlamak
}

\author{
Understanding Customer Relationship Activities of Travel Agencies from The Perspective \\ of Difference Creating Implications
}

Ülker Erdoğan ARACl', Zeki Atıl BULUT'², Berrin ONARAN ${ }^{3}$ Nilüfer KOÇAK ${ }^{4}$

\section{ÖZET}

Bu çalışmada, ilişkisel pazarlama faaliyetleri, faaliyetlerden elde edilen çıktılar ışığında değerlendirilmiştir. Bu çalışmanın amacı, uygulanan ilişkisel pazarlama faaliyetinin, söz konusu faaliyetlerden elde edilen sonucu farklılaştıı farklılaştırmadığının belirlenmesidir. Bu amaç doğrultusunda İzmir ilindeki A grubu seyahat acentelerini kapsayan tanımsal araştırma tasarımına uygun bir alan çalışması gerçekleştirilmiştir. Araştırma sonuçlarına göre, müşteriyi tanıma, müşteriyle etkileşim kurma, çalışan memnuniyeti sağlama ve çalışanlara müşteri ilişkileri yönlü eğitim verme faaliyetlerini uygulayan ve şubesi olan işletmelerin daha başarılı sonuçlara ulaştıkları tespit edilmiştir.

Anahtar Kelimeler: İlişkisel pazarlama, müşteri ilişkileri faaliyetleri, seyahat acenteleri

\section{GiRiş}

Son yıllarda pazarlama uygulama ve stratejilerinin köklü bir şekilde değişikliğe uğradığı yadsınamaz bir gerçek olarak gün yüzüne çıkmaktadır. Bilgi teknolojilerindeki hızlı gelişmeler, internetin kontrol edilemez bir şekilde ticarileşmesi, değişen dünya ekonomisi, iş hayatının olabildiğince küreselleşmesi ve müşteri değerinin artan önemi işletmeleri müşteri ilişkileri çerçevesinde yeni olgularla tanıştırmış, gelenekselden bütünsel yaklaşımlara doğru yönlendirmiştir. İlişkisel pazarlama kavramı ömür boyu müşteri değeri yaratması açısından yüksek değer ifade etmektedir. Bu açıdan irdelendiğinde, turizm endüstrisinin, üretim ve satış anlayışı dönemlerinden modern pazarlama anlayışı dönemine geçişte yaşadığı değişimleri ve değişen rekabet koşullarını, tüketici istek ve beklentileri doğrultusunda değerlendirmekte fayda vardır.

Turizm endüstrisinin en önemli parçalarından biri olan seyahat acenteleri, pazarlama sistemi içerisinde birer aracı konumundadır ve müşteriler ile turizmi sektöründeki diğer hizmet sağlayıcılarını bir araya getirirler. Turizmin küresel ekonominin temel taşların-

\begin{abstract}
In this study, the relationship marketing activities are assessed in the light of the results obtained from these activities. The aim of this study is to determine whether the aforementioned activities have any effects on the outcomes, or not. In this direction, a field study on which the desriptive study design is applicable, is done on A class travel agencies in İmir. According to the results, the firms that have branch office(s) and apply customer recognition, interacting with customers, providing employee satisfaction and training employees about customer relationship activities, have reached to better results.
\end{abstract}

Keywords: Relationship marketing, customer relationship activities, travel agencies

dan biri olmaya devam ettiği günümüzde (Tsiotsou ve Ratten, 2010) seyahat acenteleri, pazar payı yerine müşteri payını vurgulamakta böylelikle yeni başarı ölçütleri belirlemektedirler. Aracı kurum konumunda olan ve genel olarak satış ve pazarlama görevini üstlenen seyahat acenteleri için ilişkisel pazarlama faaliyetleri, müşterilerle ilişkileri hem uzun sürelere taşımak hem de üstün müşteri değeri sunma ve tatmini yaratma açısından önemlidir.

Bu bağlamda ilişkisel pazarlamanın seyahat acentelerinde müşteri değeri yaratma, hizmet kalitesini arttırma, müşteri memnuniyeti sağlama (Selvi, 2007), müşteri güveni sağlama, algılanan riski azaltma (Malley ve Prothero, 2004), çalışan performansını arttırma (Gummesson, 2002), müşteri kaybını minimize edip müşteri sayısını arttırma (Karaca, 2010), müşteri sadakati sağlama ve ağızdan ağıza reklam yoluyla müşteri sayısını arttırma şeklinde çıktılara sahip olduğu görülmektedir (Thorsten ve diğerleri, 2002). İşletmeler ilişkisel pazarlama anlayışı ile rekabetçi üstünlük elde etmenin yanı sıra, maliyetlerde küçülme, karlılıkta artış gibi doğrudan işletme performansını etkileyen yararlar da elde etmektedirler (Varinli, 2006).

\footnotetext{
1 Öğr. Gör., İzmir Üniversitesi, Meslek Yüksek Okulu, Turizm ve Otel İşletmeciliği Programı, ulker.erdogan@izmir.edu.tr

2 Öğr. Gör.Dr., Dokuz Eylül Üniversitesi, İzmir Meslek Yüksekokulu, Pazarlama Programı, atil.bulut@deu.edu.tr

${ }^{3}$ Doç. Dr., Dokuz Eylül Üniversitesi, İzmir Meslek Yüksekokulu, Pazarlama Programı, berrin.yuksel@deu.edu.tr

${ }^{4}$ Prof.Dr., Dokuz Eylül Üniversitesi, İzmir Meslek Yüksekokulu, Turizm ve Otel İşletmeciliği Programı, nilufer.kocak@deu.edu.tr
} 
Bu çalışmada, ilişkisel pazarlama faaliyetlerinin, elde edilen çıktılar bileşiminde değerlendirilmesi amaçlanmaktadır. Literatürde yer alan bu değişkenler, bu çalışmada ilişkisel pazarlama faaliyeti sonucu değişkeni olarak adlandırımış ve bu sonucun çeşitli ilişkisel pazarlama uygulamalarına göre ve bazı işletme özelliklerine göre farklılaşıp farklılaşmadığının belirlenmesi bu çalışmanın amacını oluşturmuştur.

\section{LITERATÜR INCELEMESI}

Piyasalar ilgi alanı, boyutu, ulusal kökeni ne olursa olsun neredeyse dünya çapında entegre hale gelmektedirler. Liberal ticaret politikaları, rekabet, büyüme hızının yavaşlaması gibi etkenler işletmeleri yeni arayışlara sürüklemiş̧ir. Bu kapsamda ilişkisel pazarlama, ulusal ve uluslararası pazarlarda işletmeler için farklılık ve farkındalık yaratmaktadır (Skarmeas ve Robson, 2008). il işskisel pazarlama kavramı, ilk kez 1983 yılında Leonard Berry tarafından hizmet pazarlaması üzerine yapılan bir konferansta değerlendirilmiştir ve "müşteri ilişkilerini cazibeli hale getirmek, sürdürmek ve geliştirme" olarak tanımlanmıştır. (Voss ve Voss, 1997). Literatürde, pek çok yazarın ilişkisel pazarlama tanımına yer verildiği görülmektedir. Bunlardan Hougaard ve Bjerre (2002)'e göre ilişkisel pazarlama, "rekabetçi ve karlı müşteri ilişkileri kurmak, sürdürmek ve geliştirmek amacıyla, işletme davranışlarını iki tarafın da yararı doğrultusunda şekillendirmektir". Ilişskisel pazarlamanın temel amacı ise işletmeler için önemli faydalar sağlamada etkili olan kilit unsurlar ortaya koyma ve bu unsurlar ile faydalar arasındaki nedensel ilişkinin daha iyi anlaşılmasını sağlamaktır (Thorsten ve diğerleri, 2002).

Küreselleşme ve bilgi teknolojilerindeki ilerlemeler, turizm sektöründeki önemli yapı taşlarından biri olan seyahat acentelerini de etkilemiştir. Etkileşimin boyutları, pazarlama olgusu kapsamında incelendiğinde; yönetim ve operasyonel süreçlerde bir takım değişiklikleri beraberinde getirmiştir. Illişkisel pazarlama olarak adlandırılan müşteri merkezli yeni yapı, seyahat acentelerinin yeni ekonomik düzende sahiplenmeleri gereken bir pazarlama yaklaşımı olarak yerini almıştır. Turizm ve seyahat sektörü, ilişkisel değişime yönelik uzun bir geçmişe sahiptir. Tur operatörleri geleneksel olarak oteller ve havayolu şirketleri gibi tedarikçilerle süregelen iş ilişkileri geliştirmektedirler. Pek çok tur operatörü sadık müşterileri için kulüpler oluşturmaktadır, seyahat acenteleri düzenli müşterilerini özel etkinliklere davet etmektedir. Bu faaliyetlerin yanı sıra turizm ve seyahat sektöründe faaliyet gösteren işletmeler tarafından sürekli müşteri ilişkileri sağlamak için gerçekleştirilen, sık seyahat eden kişilere sunulan ödül/puan/mil/ avantajı, otel sadakat kart- ları gibi benzeri pek çok uygulamaya rastlanmaktadır (Palmer ve Mayer, 1995). Günümüzde müşteri kayıp oranlarının azaltılması ve müşteriyi elde tutma düzeyinin arttırılmasının işletmeler için faydalı olduğu kabul edilmektedir ve literatürde müşteriyi elde tutma oranındaki artışın işletme karlılığı üzerinde etkili olduğunu gösteren pek çok çalışma yer almaktadır (Reichheld, 1993).

Buna göre, uzun süreli işletme-müşteri ilişkilerinin getirisinin yarattığı yüksek farkındalık üzerine artan bir ilginin oluşmasıyla ilişkisel pazarlama kavramının temelleri atılmıştır (Yurdakul, 2007). illişkisel pazarlama, müşteri ilişkileri yönetimi uygulamaları ile birlikte çoğunlukla hizmet pazarlaması içerisinde yer almaktadır (Gummesson 2002). Bu nedenle, hizmet işletmelerinde daha çok yer edinen ilişkisel pazarlama, hizmet işletmeleri olan turizm işletmelerinin ve seyahat acentelerinin devamlılığı açısından stratejik bir öneme sahiptir. Farklı ve rakiplerden ayırt edilebilir bir hizmet tarzı ve müşteriyle ilişki düzeyi, seyahat acentesinin başarısını belirleyen temel faktör olarak konumlanmaktadır (Doğan ve Kılıç, 2008). Karadeniz'e göre (2010), ilişkisel pazarlama, güçlü müşteri ilişkileri yaratması sebebiyle işletmelere rekabet avantajı sağlamaktadır. Rekabetçi pazarlama stratejilerinden birisi olarak ele alındığında, ilişkisel pazarlama, işletme performansını arttırmakta, bununla birlikte seyahat acenteleri özelinde, ilişkisel pazarlama hem geçmiş hem de mevcut ve potansiyel müşteri portföyüyle ilgili uygulamalar sunduğu için acentelerin ilişkili olduğu ve olacağı tüm pazarlar stratejik açıdan bir değer taşımaktadır.

İlişkisel pazarlama ile ilgili daha önce, konaklama sektöründe (Karakaş ve diğ., 2007), bankacılık sektöründe (Ndubisi, 2007), alışveriş merkezi gibi farklı alanlarda (Cheng ve Lee, 2011) yapılmış araştırmalar, ilişkisel pazarlama uygulamalarının işletmelere pek çok alanda üstünlük sağladığına dikkat çekmektedir. Bu üstünlüklerin en önemlilerinden biri olan "müşteriler tarafından daha fazla beğenilmek ve tercih edilmek" açısından bakıldığında, ilişkisel pazarlama uygulamalarına önem veren otellerin daha başarılı oldukları İlban ve diğ. tarafından (2009) ortaya konmuştur. Bu noktada ilişkisel pazarlama faaliyetlerinin müşterilerin davranışsal niyetleri üzerinde yarattığı etki, işletmeler açısından önemli bir değer ifade etmektedir (Onaran ve diğ., 2013).

Illişki pazarlamasının kilit olan üç unsuru vardır. Bunlardan birincisi iletişimdir. Bütünleşik pazarlama iletişimi, ilişki pazarlamasının önemli bir parçasıdır. Müşterilerle ilişkileri kurmak, korumak ve sürdürmek, bütünleşik bir pazarlama iletişimi ile başarılabilmektedir. (Grönroos, 2004).Uzun dönemli ilişkinin temel 
öğeleri olan memnuniyet, sadakat ve değeri oluşturmak için kaliteli hizmetin sunumu, işletme içinde çalışan personelin desteği, müşteri hakkında anlamlı bilgiler içeren veri tabanları oluşturulması ve kişiye özel hizmet sunabilecek süreçler geliştirilmesi gerekmektedir. Bu çabalar, işletmeyle müşteri arasındaki uzun dönemli ilişkiyi oluşturmak, geliştirmek ve müşteriyi elde tutmak için yürütülmesi gereken, müşteri ilişkisine odaklı işletme faaliyetleridir. Iliş̧ki pazarlaması uygulamalarının önemi ve değeri yeni müşteri edinmenin eldeki müşteriyi tutmaktan çok daha maliyetli olduğu bulgularıyla da açıklanmaktadır (Karakaş ve diğ, 2007)

Literatürdeki pek çok araştırma sonucuna göre (Karakaş ve diğ., 2007, Reichheld ve Sasser, 1990, Reichheld, 1993, Yang ve Peterson, 2004), ilişkisel pazarlama faaliyetlerinin sonuçlarından olan müşteri sadakatini doğrudan veya dolaylı olarak etkileyen en önemli araçlardan birisi müşteri memnuniyetidir. Müşteri memnuniyeti oluşturma ve kaliteli hizmetin sunumu için de çalışan memnuniyetinin sağlanması, müşteri hakkında anlamlı bilgiler içeren veri tabanları oluşturulması ve kişiye özel hizmet sunabilecek süreçlerin geliştirilmesi işletme ile müşteri arasındaki ömür boyu değer ilişkisinin kurulması açısından dikkat çekmektedir. İşletmelerin veri tabanı uygulamaları, müşterilerini tanıma ve uygun hizmet süreçlerinin oluşturulması açısından da önemlidir (Bender ve Torok, 2000: 281). Parasuraman, Berry ve Zeithaml (1991), müşterilerin hizmet verenlerden daha yakın ve daha kişiselleştirilmiş hizmet alma isteklerinin hem sürekli hem de aralıklı alınan hizmetler için geçerli olduğunu belirtmektedir. Buradan yola çıkılarak aşağıdaki hipotezler oluşturulmuştur:

$\mathrm{H}_{11}$ : Müşteriye özel hizmet sunma durumuna göre, seyahat acentelerindeki ilişkisel pazarlama faaliyeti sonuçları arasında fark vardır.

$\mathrm{H}_{11}$ : Müşteri tanıma faaliyetlerinin uygulanma durumuna göre, seyahat acentelerindeki ilişkisel pazarlama faaliyeti sonuçları arasında fark vardır.

İlişkisel pazarlamanın özü, müşteriyle karşılıklı etkileşimin yönetimidir. Karşılıklı etkilişim, ilişki pazarlamasının iletişimden sonraki ikinci kilit unsurudur. İlişki pazarlaması, pazarlamanın merkezinde ürünün değil müşterilerin yer aldığı ve müşteriye değer yaratma sürecini içeren bir yapıdadır. Paylaşım için bir diyalog sürecinin kurulması ve karşılıklı bilgi alışverişiyle sağlanacak olan etkileşim ilişki pazarlamasının temelini oluşturmaktadır. Bu süreçte işletmeler, insanlar, teknoloji veya kurdukları sistemler aracılığıyla müşterileriyle etkileşim kurarlar ve bilgilerini müşterilerine sunarlar (Grönroos, 2004). İşletmeler müşterilerini değer ve beklentilerine göre farklılaştırarak, işletme için değerli olan müşterilerle etkileşime girmektedirler. Etkileşimler sonucu elde edilen bilgiler kullanılarak ürün veya hizmet bu müşterilerin beklenti ve ihtiyaçları doğrultusunda şekillendirildiğinde, ilişkisel pazarlama uygulamalarının başarı olasılığı artmaktadır (Selvi, 2007:65). Bu uygulamalara göre ilişkisel pazarlama sonuçlarının farklılaşıp farklılaşmadığının belirlenmesi için aşağıdaki hipotezler oluşturulmuştur:

$\mathrm{H}_{11}$ : Farklı müşterilere farklı davranma durumuna göre, seyahat acentelerindeki ilişkisel pazarlama faaliyeti sonuçları arasında fark vardır.

$\mathrm{H}_{1 \mathrm{~d}}$ : Müşteriyle etkileşim kurma durumuna göre, seyahat acentelerindeki ilişkisel pazarlama faaliyeti sonuçları arasında fark vardır.

İlişkisel pazarlamanın odaklandığı diğer bir konu olan gizlilik ve güven sağlama, işletme ve müşteri arasındaki ilişkinin süresini uzatması açısından önemli görülmektedir (Sin ve diğ., 2005:188). Güven genellikle başarılı ilişkilerin temel parçalarından biridir. Güven, kişinin gerçekten güvenilir olduğunu hissettiği satış temsilcisi, seyahat acentesi gibi bir değişim ortağına inanması ve güven duyması konusundaki gönüllülük olarak tanımlanabilir (Garbarino ve Johnson, 1999). Gwinner, Gremler ve Bitner (1998), hizmet işletmelerinde müşteri ile ilişkilerde yaratılacak güvenin müşteriye özel davranma veya sosyal fayda sağlamaktan çok daha önemli olduğunu ve psikolojik bir fayda yarattığını öne sürmektedir. Hacıefendioğlu ve Çolular (2008) ise güven oluşturmada etkili olan faktörler yoluyla ilişkisel pazarlamadan sağlanan yararın artacağını işaret etmiştir. Bu bağlamda kendini güvende hisseden müşteri, kendiyle ilgili bilgileri işletme ile rahatlıkla paylaşacak ve işletmenin kendisine sunduğu alternatifleri güvenle benimseyecektir. Bu varsayımdan hareketle aşağıdaki hipotez oluşturulmuştur:

$\mathrm{H}_{1 \mathrm{e}}$ : Gizlilik ve güven sağlamaya göre, seyahat acentelerindeki ilişkisel pazarlama faaliyeti sonuçları arasında fark vardır

Sarıdaldı ve Sevim'e göre (2009:110) müşteri sadakatinin oluşturulmasında, diğer bir deyişle ilişkisel pazarlamanın başarısında, etkili olan araçlardan biri olarak müşteri şikayetlerini dikkate alma; işletmeler için hizmet kalitesine ilişkin eksiklerin belirlenmesinde, müşteri memnuniyetinin önündeki engellerin tespit edilmesinde ve daha iyi hizmet sunumunda diğer önemli kilit faktörlerden biri olarak yerini almaktadır. Şikayetlerin etkili bir şekilde ele alınması müşteriyi elde tutma oranını, ağızdan ağza yayılan olumsuzlukları olumluya çevirmeyi ve düşük düzeydeki performansın arttııımasını da sağlayan önemli 
bir etkiye sahiptir ve müşteri şikayetlerinin çözümü, müşteri tatmini ve güveni gibi -bu çalışmada ilişkisel pazarlama faaliyeti sonucu olarak ele alınan- faktörlerle doğrudan ilişkilidir (Tax, Brown ve Chandrashekaran, 1998). Bu görüşten hareketle müşteri şikayetlerini dikkate alan ve almayan acentelerin elde ettiği ilişkisel pazarlama faaliyetleri sonuçları arasında fark olup olmadığının incelenmesi için aşağıdaki hipotez oluşturulmuştur:

$\mathrm{H}_{1 f}:$ Müşteri şikayetlerini dikkate alma durumuna göre, seyahat acentelerindeki ilişkisel pazarlama faaliyeti sonuçları arasında fark vardır.

Müşterinin ilişkide olduğu işletme tarafından her defasında hatırlanması, müşteri sadakatini arttıran diğer bir ilişkisel pazarlama faaliyetidir. Özellikle zamanın gittikçe önem kazanan bir faktör olduğu günümüzde, müşterinin isteklerini tahmin edebilen işletmelerin daha başarılı çıktılar elde etmesi beklenmektedir. Çünkü müşteri pazardaki diğer işletmelerle ilişki kurmaktansa kendisini tanıyan işletme ile ilişkisini sürdürecek ve işletmeye sadık kalacaktır (Erbaşlar, 2009:31). Buradan hareketle müşteriyi bir sonraki ziyaretinde hatırlama faaliyetinin etkisinin ölçülmesi amacıyla aşağıdaki hipotez oluşturulmuştur:

$\mathrm{H}_{1 \mathrm{~g}}$ : Müş̧teriyi bir sonraki ziyaretinde hatırlama durumuna göre, seyahat acentelerindeki ilişkisel pazarlama faaliyeti sonuçları arasında fark vardır.

Müşteri için değer, ilişkide olduğu işletmenin tek bir nitelikle ilgili konumlandırmasından daha fazlasıdır (Kotler, 2011). Müşteri açısından değer yaratma kavramı, müşterinin ödediği bedel karşıığında, beklediğinden fazlasını elde ettiği zamanki durumu ve anlamı içermektedir. Bu açıdan ele alındığında işletme açısından değer yaratma, müşteriye cazip gelecek ek yararları bir bedel ödetmeden onlara sunmaktır (Çalışkan, 2008). Değer, ilişki pazarlamasında etkileşimin sonucu olarak yaratılan bir diğer unsurdur. Değer yaratma, müşterinin içsel süreçlerini anlamayla geliştirilmelidir. Müşteri ihtiyaçlarına en uygun çözümler karşılıklı etkileşim ve iletişim süreci içinde müşterilere sunulmalıdır (Grönroos, 2004). Bu kapsamda, işletmeler tarafından kullanılan veri tabanları, müşteriye ek yararlar sağlaması açısından stratejik öneme sahiptir. Seyahat acentelerinin müşterilerine özel günler için yaptığı sunumlar, cezbedici alternatif tatil programları ve sürprizler, yoğun rekabet pazarında fark yaratabilmeleri için değer ifade etmektedir. Bu ilişkisel pazarlama faaliyetleri uygulayan ve uygulamayan işletmelerin elde ettiği ilişkisel pazarlama faaliyetleri sonuçları arasında fark olup olmadığının incelenmesi amacıyla şu hipotez oluşturulmuştur:

$\mathrm{H}_{1 \mathrm{~h}}$ : Özel günleri hatırlama ve alternatifler sunma durumuna göre, seyahat acentelerindeki ilişkisel pazarlama faaliyeti sonuçları arasında fark vardır.
İsletmelerin çağrı merkezine sahip olma durumlarına göre de ilişkisel pazarlama uygulamaları farklı etkilere sahip olabilmektedir. Çağrı merkezi sayesinde arayan müşteri istediği konuya ilişkin bilgi alabilmektedir. Böylece işletmeler en çok sorulan soruları belirleyip, bilgi temelli çözümler üretebilmektedirler. Ayrıca arama merkezleri sayesinde, müşterilerin ihtiyaçları belirlenebilmekte ve müşteride güven imajı oluşmaktadır (Erbaşlar, 2009). Çağrı merkezi sahipliğinin ilişkisel pazarlama faaliyeti sonuçları üzerindeki etkisinin incelenmesi için sıradaki hipotez oluşturulmuştur:

$\mathrm{H}_{1:}$ : Çağrı merkezine sahip olma durumuna göre, seyahat acentelerindeki ilişkisel pazarlama faaliyeti sonuçları arasında fark vardır.

illişki pazarlamasında işletmeler içerisinde işbirliğinin oluşması ve işletme bölümleri arası bütünsel çabaların gösterilmesinde müşteri ilişkileri eğitiminin, etkin bir yöntem olduğu düşünülmektedir. Müşteri ilişkileri eğitimi, personelin gelişimine ve işletme amaçlarını benimsemesine yardımcı olmaktadır. Böylece işletme kültürünü, kimliğini kavramış çalışanlar, daha yüksek kalitede hizmet üretimi gerçekleştirecek, müşterinin daha fazla satın alım yapmasını ve işletme ile daha yakın ilişkiler kurmasını sağlayacaktır (Selvi, 2007). O'Malley ve Tynan (2003), ilişkisel pazarlamanın uygulanabilmesini kolaylaştırmak için yöneticilerin ihtiyaç duyduğu faaliyetlerden birisinin çalışanlara ilişkisel pazarlama yönlü eğitim vermek olduğunu belirtmektedir. Çünkü müşteriyle karşı karşıya gelen çalışanlarda müşteriyle ilişki kurma becerilerini geliştirmeye daha fazla dikkat edilmesi gerekmektedir. Buradan hareketle çalışanlara yönelik ilişkisel pazarlama uygulamalarının ve müşteri ilişkileri yönlü eğitimin, ilişkisel pazarlama faaliyetleri sonuçlarını farklılaştırıp farklılaştırmadığının incelenmesi için şu hipotezler oluşturulmuştur:

$H_{1 j}$ : Çalışanlara müşteri ilişkileri yönlü eğitim verme durumuna göre, seyahat acentelerindeki ilişkisel pazarlama faaliyeti sonuçları arasında fark vardır.

$\mathrm{H}_{1 \mathrm{k}}$ : Çalışan memnuniyeti sağlama durumuna göre, seyahat acentelerindeki ilişkisel pazarlama faaliyeti sonuçları arasında fark vardır.

İlişki pazarlaması uygulamalarından müşteri sadakat programları ile çevresindeki çok sayıdaki seçenekleri değerlendirmeyip işletmeyi ve işletmenin ürün ya da markalarını tercih eden müşterilere bu bağlııklarının karşılığı verilmektedir. Bu karşılık kimi zaman parasal ödüller olurken, kimi zaman da ayrıcalık sağlayan uygulamalar olabilmektedir (Yurdakul, 2007). Bu noktada sadakat kartı sunumu, ödüllendirme programları ve özel fiyat indirimleri ile müşteriler ve işlet- 
me arasında ömür boyu değer ilişkisi yaratılmakta ve bağın güçlenmesi sağlanmaktadır. Bu uygulamalara göre elde edilen ilişkisel pazarlama faaliyeti sonuçları arasındaki farkların incelenmesi amacıyla üç hipotez oluşturulmuştur:

$\mathrm{H}_{11}$ : Ödüllendirme programları uygulamalarına göre, seyahat acentelerindeki ilişkisel pazarlama faaliyeti sonuçları arasında fark vardır.

$\mathrm{H}_{1 \mathrm{~m}:}$ Sadakat kartı sunma durumuna göre, seyahat acentelerindeki ilişkisel pazarlama faaliyeti sonuçları arasında fark vardır.

$H_{1 n:}$ Özel fiyat indirimleri sunma durumuna göre, seyahat acentelerindeki ilişkisel pazarlama faaliyeti sonuçları arasında fark vardır.

Literatür taraması doğrultusunda araştırmada test edilmek üzere oluşturulan hipotezler dışında işletmelerin çalıştırdıkları kadrolu personel sayısı, stajyer sayısı, şube sahipliği ve kuruluş yıılına göre elde edilen ilişkisel pazarlama faaliyeti sonuçlarının karşılaştırılması için de dört adet hipotez oluşturumuştur:

$\mathrm{H}_{10}$ Kadrolu personel sayısına göre, seyahat acentelerindeki ilişkisel pazarlama faaliyeti sonuçları arasında fark vardır.

$\mathrm{H}_{1 \mathrm{p} \text { : }}$ Stajyer personel sayısına göre, seyahat acentelerindeki ilişkisel pazarlama faaliyeti sonuçları arasında fark vardır.

$H_{1 \text { 1: }}$ Şube sahibi olup olmamasına göre, seyahat acentelerindeki ilişkisel pazarlama faaliyeti sonuçları arasında fark vardır.

$H_{15:}$ Kuruluş yılına göre, seyahat acentelerindeki ilişkisel pazarlama faaliyeti sonuçları arasında fark vardır.

\section{ARAŞTIRMANIN YÖNTEMI}

\subsection{Araştırma Tasarımı, Örneklem ve Veri Top-} lama

Literatür taraması sonucunda "seyahat acentelerinde uygulanan ilişkisel pazarlama faaliyetlerinin sonuçları, kullanılan ilişkisel pazarlama faaliyetlerinin türüne göre farklılaşmakta mıdır?" sorusu araştırma problemi olarak tanımlanmış ve bu problemin çözümü ve hipotezlerin test edilmesi amacıyla tanımsal araştırma tasarımına uygun bir alan araştırması planlanmıştır.

Araştırmanın evrenini İzmir ilindeki A grubu seyahat acenteleri oluşturmaktadır. Araştırma evreni olarak A grubu acentelerinin seçilmesinin nedeni bu acentelerin faaliyet alanlarının daha geniş ve profesyonelleşme düzeylerinin daha fazla olmasıdır. Bu seçim doğrultusunda ilişkisel pazarlama faaliyetlerini bilinçli bir şekilde uygulayan ve uygulamayan acentelerin karşılaştırılmasının daha doğru sonuçlar vereceği varsayılmıştır. Araştırmada İzmir'de yer alan 249 A grubu seyahat acentesinden 8 tanesi TÜRSAB'a kayıtlı adreslerinde bulunamadığı için evrenden çıkarılmış, örneklem çerçevesi 241 olarak tespit edilmiş ve bu acentelerin tamamına ulaşılarak tam sayım yapılmış, bu nedenle örnekleme yapılmamıştır.

Örneklem çerçevesini oluşturan seyahat acentelerinden ilişkisel pazarlama faaliyetlerine yönelik verilerin elde edilmesi için birincil veri toplama araçlarından anket kullanılmıştır. Anket uygulaması acente yöneticileriyle yüzyüze görüşme şekilde yapılmıştır. Acentelerden 50'si araştırmaya katılmak istememiş, 41 acenteden ise konuyla ilgili yöneticilere ulaşılamadığı için veri toplanamamıştır. Dolayısıyla toplam 150 acenteden veri toplanmış ve anketin geri dönüş oranı \%62.2 olarak tespit edilmiştir. Elde edilen bu örnek büyüklüğü aynı zamanda ana kütleyi temsil etmeye yetecek örneklem büyüklüğünü kapsamaktadır (Saunders, Lewis, Thornhill, 2000: 156).

Araştırmada kullanılan anket formu iki bölümden oluşmaktadır. İlk bölümde acentelerin ilişkisel pazarlama faaliyetlerinin sonuçlarının ölçülmesine yönelik olarak Altunöz (2006) tarafından hazırlanan ölçekten ve literatür incelemesinden yararlanılarak hazırlanan beşli Likert ölçekte (1-kesinlikle katılmıyorum; 5- kesinlikle katılıyorum) 9 soru, ikinci bölümde ise, acentelerin uyguladıkları ilişkisel pazarlama faaliyetlerine ilişkin hazırlanmış olan dikotom ölçekte 15 soru yer almaktadır. İlişkisel pazarlama faaliyetlerinin sonucu olarak adlandırılan değişken, literatür taramasından elde edilen bulgulardaki ilişkisel pazarlama sonuçları olan dokuz değişkenin (müşteri değeri yaratma, hizmet kalitesini arttırma, müşteri memnuniyeti sağlama, müşteri güveni sağlama, algılanan riski azaltma, çalışan performansını arttırma, müşteri sayısını arttırma, müşteri sadakati sağlama ve ağızdan ağıza reklam) birleşiminden oluşmaktadır. Acentelerin ilişkisel pazarlama faaliyetlerinin sonuçlarının ölçüldüğü sorularda yöneticilerin, kendi görüşlerini belirtmeleri değil, acentelerin elde ettiği sonuçları yansıtacak şekilde soruları yanıtlamalarına özellikle dikkat edilmiştir.

Anket formu hazırlandıktan sonra 33 acente yöneticisiyle pilot uygulama yapılmış ve ifadelerin anlaşılabilirliği ve ilişkisel pazarlama faaliyetlerinin sonuçlarına yönelik ölçeğin güvenilirliği incelenmiştir. Elde edilen sonuç ve önerilere göre ifadelerde küçük düzeltmeler yapılmıştır. Ölçeğin pilot çalışmadaki güvenilirliği ise $\mathrm{a}: .817$ olarak bulunmuştur.

\subsection{Analiz Yöntemi}

Çalışmada, acentelerden toplanan verilere ilişkin tanımlayıcı analizler, güvenilirlik katsayısı ve hipotezler SPSS 19.0 programıyla test edilmiştir. Tanımsal analizler ve hipotez testlerine geçilmeden önce, 
ilişkisel pazarlama faaliyetlerinin sonucuna yönelik ölçeğin güvenilirliği test edilmiş ve $a:$ : 819 olarak bulunmuştur. Bu sonuca göre ölçeğin güvenilir olduğu sonucuna ulaşılarak diğer analizlere geçilmiştir. Frekans analizleri ile tanımlayıcı bulgular ortaya konulmuş, hipotez testi olarak hangi analizin kullanılacağının belirlenmesi için öncelikli olarak verilerin normal dağılıma uygunluğunun tespit edilmesine yönelik olarak Kolmogorov-Smirnov analizi yapılmıştır. Analiz sonuçlarına göre tüm değişkenler için p:.000<0.05 olduğunda verilerin normal dağılıma uygun olmadığı tespit edilmiştir. Bu nedenle ilişkisel pazarlama faaliyetlerini uygulayan ve uygulamayan işletmelerin ilişkisel pazarlama faaliyetleri sonuçlarının farklılaşıp farklılaşmadığına ve bazı işletme özelliklerine göre bu sonuçların farklılaşıp farklılaşmadığına yönelik hipo- tezlerin test edilmesi için Mann-Whitney $U$ testi, işletmenin kuruluş yılına göre elde edilen ilişkisel pazarlama faaliyeti sonuçlarının farklılaşıp farklılaşmadığının belirlenmesine yönelik hipotezin test edilmesi içinse Kruskall Wallis $\mathrm{H}$ testi kullanılmıştır.

\section{BULGULAR}

\subsection{Tanımlayıcı Bulgular}

Araştrmaya katılan acentelere ilişkin tanımlayıcı özellikler ve ilişkisel pazarlama faaliyetlerinin sonuçları frekans analizleri ile ortaya konulmuştur. Acentelerin çeşitli özellikleri ve uyguladıkları ilişkisel pazarlama faaliyetlerine yönelik bulgular Tablo 1'de gösterilmektedir.

Tablo 1: Tanımlayıcı Bulgular

\begin{tabular}{|l|c|c|l|c|c|}
\hline \multicolumn{1}{|c|}{ Kuruluş Yılı } & $\mathrm{n}$ & $\%$ & \multicolumn{1}{c|}{$\begin{array}{c}\text { Personel Sayısı } \\
\text { (Kadrolu) }\end{array}$} & $\mathrm{n}$ & $\%$ \\
\hline 1989 ve öncesi & 29 & 19,3 & 10 kişi ve daha az & 123 & 82,0 \\
\hline $1990-2000$ & 58 & 38,7 & $11-20$ kişi & 23 & 15,3 \\
\hline $2001-2012$ & 63 & 42,0 & 21 ve üzeri & 4 & 2,7 \\
\hline \multicolumn{1}{|c|}{ Şube Sayısı } & $\mathrm{n}$ & $\%$ & \multicolumn{1}{|c|}{ Personel Sayısı (Stajyer) } & $\mathrm{n}$ & $\%$ \\
\hline Şube yok & 81 & 54,0 & 10 kişi ve daha az & 112 & 74,7 \\
\hline $1-10$ şube & 67 & 44,7 & $11-20$ kişi & 36 & 24,0 \\
\hline 11 ve üzeri & 2 & 1,3 & 21 ve üzeri & 2 & 1,3 \\
\hline \multicolumn{1}{|c|}{ Uygulanan Faaliyet } & $\mathrm{n}$ & $\%$ & \multicolumn{1}{c|}{ Uygulanan Faaliyet } & $\mathrm{n}$ & $\%$ \\
\hline $\begin{array}{l}\text { Müşteri Şikâyetlerini Dikkate } \\
\text { Alma }\end{array}$ & 138 & 94,5 & $\begin{array}{l}\text { Özel Günleri Hatırlama ve } \\
\text { Alternatifler Sunma }\end{array}$ & 77 & 52,7 \\
\hline Müşteriyi Tanıma & 122 & 83,6 & $\begin{array}{l}\text { Çalışanlara Müşteri llişkileri Yönlü } \\
\text { Eğitim Verme }\end{array}$ & 73 & 50,0 \\
\hline Müşteriye Özel Hizmet Sunma & 120 & 82,2 & Farklı Müşterilere Farklı Davranma & 71 & 48,6 \\
\hline Özel Fiyat İndirimleri & 118 & 80,8 & Çağrı Merkezleri Oluşturma & 48 & 32,9 \\
\hline Gizlilik ve Güven Sağlama & 117 & 80,1 & Sıklık Programları (ödüllendirme) & 30 & 20,5 \\
\hline $\begin{array}{l}\text { Müşteriyi Bir Sonraki } \\
\text { Ziyaretinde Hatırlama }\end{array}$ & 116 & 79,5 & Sadakat Kartı & 13 & 8,9 \\
\hline Müşteriyle Etkileşim Kurma & 110 & 75,3 & Veri Tabanı Sahipliği & 144 & 98,6 \\
\hline Çalışan Memnuniyeti Sağlama & 95 & 65,1 & & & \\
\hline
\end{tabular}

Elde edilen sonuçlara göre, araştırmaya katılan acentelerin yarısından fazlasının 2000 yılı ve öncesinde kurulduğu, şubelerinin olmadığı ve 10 veya daha az çalışana ve stajyere sahip olduğu belirlenmiştir. Bununla birlikte acentelerin ilişkisel pazarlama faaliyetlerini kullanma oranları incelendiğinde, en sık kullanılan ilişkisel pazarlama faaliyetinin müşteri şikayetlerinin dikkate alınması olduğu, bunu sırasıyla müşteriyi tanıma, müşteriye özel hizmet sunma ve özel fiyat indirimleri sunmanın izlediği ortaya konmuştur. Ayrıca işletmelerin tamamına yakınının veri tabanına sahip olduğu belirlenmiştir. Buna karşın, acentelerin yalnızca \% 8,9'unun sadakat kartına sahip olduğu ve \% 20'ye yakınının sıklık (ödüllendirme) programı kullandığı belirlenmiştir. Acentelerin ilişkisel pazarlama faaliyetlerinden elde ettikleri sonuçlara ilişkin frekans analizi sonuçları Tablo 2'de gösterilmektedir. 
Tablo 2: İlişkisel Pazarlama Faaliyetleri Sonuçlarına İlişkin Frekans Analizi Sonuçları

\begin{tabular}{|c|c|c|c|c|c|c|}
\hline \multirow{2}{*}{ İfadeler (1- kesinlikle katılmıyorum; 5-kesinlikle katılıyorum) } & 1 & 2 & 3 & 4 & 5 & \\
\hline & $\%$ & $\%$ & $\%$ & $\%$ & $\%$ & $\bar{X}$ \\
\hline $\begin{array}{l}\text { D1 - İliş̧kisel pazarlama faaliyetleri, seyahat acentelerinde müşteri değeri } \\
\text { yaratmaktadır. }\end{array}$ & 0 & 0 & 0,7 & 32,9 & 66,4 & 4,66 \\
\hline $\begin{array}{l}\text { D2 - İlişkisel pazarlama faaliyetleri, seyahat acentelerinin müşteri sayısını } \\
\text { arttırmaktadır. }\end{array}$ & 0 & 0,7 & 3,4 & 32,9 & 63,0 & 4,58 \\
\hline $\begin{array}{l}\text { D3 - İlişkisel pazarlama faaliyetleri, seyahat acentelerinde müşteri memnuniyeti } \\
\text { sağlamaktadır. }\end{array}$ & 0 & 0 & 4,8 & 28,1 & 67,1 & 4,62 \\
\hline $\begin{array}{l}\text { D4 - İlişkisel pazarlama faaliyetleri, seyahat acentelerinde hizmet kalitesini } \\
\text { arttırmaktadır. }\end{array}$ & 0,7 & 0,7 & 8,7 & 35,3 & 52,0 & 4,41 \\
\hline D5 - İlişkisel pazarlama faaliyetleri, uzun vadeli müşteri ilişkilerini sağlamaktadır. & 0 & 2,1 & 5,5 & 33,5 & 58,9 & 4,49 \\
\hline $\begin{array}{l}\text { D6 - İlişkisel pazarlama faaliyetleri, müşterilerin acenteye olan güvenini } \\
\text { arttırmaktadır. }\end{array}$ & 0 & 1,4 & 5,5 & 34,9 & 58,2 & 4,50 \\
\hline $\begin{array}{l}\text { D7 - İlişkisel pazarlama faaliyeti olarak eğitim sonucu çalışan performansındaki } \\
\text { gelişimin ödüllendirilmesi, çalışan memnuniyetini arttırmaktadır. }\end{array}$ & 0 & 0,7 & 8,9 & 34,9 & 55,5 & 4,45 \\
\hline D8 - İlişkisel pazarlama faaliyetleri, müşteri açısından algılanan riski azaltmaktadır. & 1,4 & 2,1 & 17,1 & 39,0 & 40,4 & 4,15 \\
\hline $\begin{array}{l}\text { D9 - İlişkisel pazarlama faaliyetleri sonucu müşterilerin ağızdan ağıza reklam } \\
\text { yapması, yeni müşteri kazanılmasını sağlamaktadır. }\end{array}$ & 0 & 0,7 & 4,8 & 37,7 & 56,8 & 4,51 \\
\hline
\end{tabular}

Analiz sonuçlarına göre, en yüksek ortalamaya sahip ilişkisel pazarlama faaliyeti sonucunun müşteri değeri yaratmak olduğu, en düşük ortalamaya sahip olan ilişkisel pazarlama faaliyeti sonucunun ise müşterinin algıladığı riskin azalması olduğu tespit edilmiştir. İlişkisel pazarlama faaliyetlerinin sonuçlarına yönelik bu bulgular, uygulanan ilişkisel pazarlama faaliyetleriyle ilişkilendirilerek araştırma hipotezleri test edilmiştir.

\subsection{Hipotez Testleri}

Acentelerin elde ettiği ilişkisel pazarlama faaliyetleri sonuçlarının uygulanan faaliyetlere, işletmelerin kuruluş yılına, personel ve stajyer sayılarına ve şube sahipliğine göre farklılaşıp farklılaşmadığına yönelik olarak kurulan araştırma hipotezleri Mann-Whitney U testi ve Kruskal Wallis $\mathrm{H}$ testi ile test edilmiştir. Hipotez testi sonuçları Tablo 3'de gösterilmektedir. 
Tablo 3: Hipotez Testi Sonuçları

\begin{tabular}{|c|c|c|c|c|c|c|c|}
\hline \multirow{2}{*}{ Değişken } & \multicolumn{7}{|c|}{ İlişkisel Pazarlama Faaliyeti Türleri } \\
\hline & Müşteriye Özel Hizmet Sunma & $\mathrm{n}$ & S.O. & $\mathrm{U}$ & Z & $p$ & $\mathrm{~K} / \mathrm{R}$ \\
\hline \multirow{54}{*}{$\begin{array}{l}\text { İlişkisel pazarlama } \\
\text { uygulamalarından } \\
\text { elde edilen sonuçlar }\end{array}$} & Uyguluyor & 120 & 75,12 & \multirow{2}{*}{1366,0} & \multirow{2}{*}{$-1,000$} & \multirow{2}{*}{,318 } & \multirow{2}{*}{$\mathrm{R}$} \\
\hline & Uygulamıyor & 26 & 66,04 & & & & \\
\hline & Farklı Müşterilere Farklı Davranma & $\mathrm{n}$ & S.O. & $\mathrm{U}$ & Z & $\mathrm{p}$ & \multirow{3}{*}{$\mathrm{R}$} \\
\hline & Uyguluyor & 71 & 77,48 & \multirow{2}{*}{2380,0} & \multirow{2}{*}{$-1,114$} & \multirow{2}{*}{265} & \\
\hline & Uygulamıyor & 75 & 69,73 & & & & \\
\hline & Gizlilik ve Güven Sağlama & $\mathrm{n}$ & S.O. & $\mathrm{U}$ & Z & $\mathrm{p}$ & \multirow{3}{*}{$\mathrm{R}$} \\
\hline & Uyguluyor & 117 & 76,80 & \multirow{2}{*}{1310,5} & \multirow{2}{*}{$-1,907$} & \multirow{2}{*}{057} & \\
\hline & Uygulamıyor & 29 & 60,19 & & & & \\
\hline & Müşteriyi Tanıma & $\mathrm{n}$ & S.O. & $\mathrm{U}$ & Z & $p$ & \multirow{3}{*}{$\mathrm{K}$} \\
\hline & Uyguluyor & 122 & 77,02 & \multirow{2}{*}{1034,0} & & & \\
\hline & Uygulamiyor & 24 & 55,58 & & $-2,28 /$ &, 022 & \\
\hline & Müşteri Şikayetlerini Dikkate Alma & $\mathrm{n}$ & S.O. & $\mathrm{U}$ & Z & $\mathrm{p}$ & \\
\hline & Uyguluyor & 138 & 74,93 & & & & $\mathrm{R}$ \\
\hline & Uygulamıyor & 8 & 48,75 & 354,0 & $-1,715$ & ,086 & \\
\hline & Müşteriyle Etkileşim Kurma & $\mathrm{n}$ & S.O. & $\mathrm{U}$ & Z & $p$ & \\
\hline & Uyguluyor & 110 & 79,20 & 13535 & -2865 & 004 & K \\
\hline & Uygulamıyor & 36 & 56,10 & 1353,5 & $-2,865$ &, 004 & \\
\hline & Müşteriyi Bir Sonraki Ziyaretinde Hatırlama & $\mathrm{n}$ & S.O. & $\mathrm{U}$ & Z & $\mathrm{p}$ & \\
\hline & Uyguluyor & 116 & 76,35 & & -1612 & & $\mathrm{R}$ \\
\hline & Uygulamıyor & 30 & 62,48 & 1409,5 & $-1,612$ &, 107 & \\
\hline & Özel Günleri Hatırlama ve Alternatifler Sunma & $\mathrm{n}$ & S.O. & $\mathrm{U}$ & Z & $p$ & \\
\hline & Uyguluyor & 77 & 75,77 & 24815 & -691 & 490 & $\mathrm{R}$ \\
\hline & Uygulamıyor & 69 & 70,96 & 2481,5 & - &, 490 & \\
\hline & Çağrı Merkezleri Oluşturma & $\mathrm{n}$ & S.O. & $\mathrm{U}$ & Z & $p$ & \\
\hline & Uyguluyor & 48 & 77,13 & 21780 & & & $\mathrm{R}$ \\
\hline & Uygulamıyor & 98 & 71,72 & $21 / 8,0$ &,$- / 30$ & ,465 & \\
\hline & Çalışanlara Müşteri Illişkileri Yönlü Eğitim Verme & $\mathrm{n}$ & S.O. & $U$ & Z & $p$ & \\
\hline & Uyguluyor & 73 & 81,77 & $2060-$ & 201 & 017 & $\mathrm{~K}$ \\
\hline & Uygulamıyor & 73 & 65,23 & 2000,3 & $-2,301$ & ו & \\
\hline & Çalışan Memnuniyeti Sağlama & $\mathrm{n}$ & S.O. & $\mathrm{U}$ & Z & $\mathrm{p}$ & \\
\hline & Uyguluyor & 95 & 80,13 & 17925 & -2605 & 009 & $\mathrm{~K}$ \\
\hline & Uygulamıyor & 51 & 61,15 & $1 / 92,5$ & $-2,605$ & ,009 & \\
\hline & Sıklık Programları & $\mathrm{n}$ & S.O. & $\mathrm{U}$ & Z & $p$ & \\
\hline & Uyguluyor & 30 & 84,92 & 1397.5 & -1.671 & 095 & $\mathrm{R}$ \\
\hline & Uygulamıyor & 116 & 70,55 & 1391,3 & $-1,0 / 1$ & & \\
\hline & Sadakat Kartı & $\mathrm{n}$ & S.O. & $\mathrm{U}$ & Z & $p$ & \\
\hline & Uyguluyor & 13 & 95,23 & 5820 & 1955 & 051 & $\mathrm{R}$ \\
\hline & Uygulamıyor & 133 & 71,38 & 582,0 & $-1,953$ & 1 & \\
\hline & Özel Fiyat Indirimleri & $\mathrm{n}$ & S.O. & $U$ & Z & $p$ & \\
\hline & Uyguluyor & 118 & 76,70 & 12745 & -1890 & 059 & $\mathrm{R}$ \\
\hline & Uygulamıyor & 28 & 60,02 & 1274,3 & $-1,080$ & (039) & \\
\hline & Kadrolu Personel Sayısı & $\mathrm{n}$ & S.O. & U & Z & $p$ & \\
\hline & 10 kişi ve daha az & 120 & 72,15 & 13985 & -832 & 405 & $\mathrm{R}$ \\
\hline & 11 kişi ve daha fazla & 26 & 79,71 & & 年, & , & \\
\hline & Stajyer Personel Sayısı & $\mathrm{n}$ & S.O. & $\mathrm{U}$ & Z & $p$ & \\
\hline & 10 kişi ve daha az & 110 & 75,81 & 17260 & ב 16 & 245 & $\mathrm{R}$ \\
\hline & 11 kişi ve daha fazla & 36 & 66,44 & $1 / \angle 0,0$ & $-1,102$ &, 245 & \\
\hline & Şube Sahipliği & $\mathrm{n}$ & S.O. & $\mathrm{U}$ & Z & $p$ & \\
\hline & Şubesi yok & 81 & 66,72 & 20830 & -2179 & 029 & $\mathrm{~K}$ \\
\hline & Şubesi var & 65 & 81,95 & 2083,0 & $-2,1 / 9$ & ,029 & \\
\hline & Kuruluş Yılı* & $\mathrm{n}$ & S.O. & Ki-kare & df & $\mathrm{p}$ & \\
\hline & 1989 ve öncesi & 29 & 74,83 & & & & R \\
\hline & $1990-2000$ & 56 & 72,45 & ,068 & 2 & 966 & \\
\hline & 2001 ve sonrası & 61 & 73,84 & & & & \\
\hline
\end{tabular}

( Not: S.O.: Sıra Ortalaması K/R: Hipotezin Kabul veya Reddedildiği df: serbestlik derecesi * kuruluş yılına göre elde edilen sonuçların karşılaştırılmasında Kruskal Wallis $\mathrm{H}$ testi kullanılmıştır.) 
Hipotez testi sonuçlarına göre, acentelerin ilişkisel pazarlama faaliyetlerinin sonuçlarının bazı değişkenlere göre farklılık gösterdiği tespit edilmiştir. Acentelerin müşteriyi tanıma faaliyetleri uygulayıp uygulamamaları (U:1034,0; Z:-2,287; p: ,022), müşteriyle etkileşim kurup kurmamaları (U:1353,5; Z:-2,865; p: ,004), çalışanlara müşteri ilişkileri yönlü eğitim verip vermemeleri (U:2060,5; Z:-2,381; p: ,017) ve çalışan memnuniyeti sağlayıp sağlamamaları (U:1792,5; Z:-2,605; p: ,009), ilişkisel pazarlama faaliyetleri sonuçlarını farklılaştırmaktadır. Benzer şekilde şubesi olan işletmelerin de ilişkisel pazarlama faaliyetleri sonuçlarını şubesi olmayanlara göre anlamlı derecede farklılaştırmaktadır (U:2083,0; Z:-2,179; p: ,029) Analiz sonuçlarına göre, bu faaliyetleri uygulayan ve şubesi olan acentelerin ve ilişkisel pazarlama faaliyetleri sonuçlarının, uygulamayan ve şubesi olmayan acentelere göre daha başarılı olduğu tespit edilmiştir.

Acentelerin müşteri ilişkileri pazarlaması sonuçlarının acentelerin uyguladığı/uygulamadığı diğer ilişkisel pazarlama faaliyetlerine göre ise farklılaşmadığı tespit edilmiştir. Buna göre araştırma hipotezlerinden $\mathrm{H}_{1 b^{\prime}}, \mathrm{H}_{1 \mathrm{~d}}, \mathrm{H}_{1 j}, \mathrm{H}_{1 \mathrm{k}}, \mathrm{H}_{1 \mathrm{r}}$, hipotezleri kabul edilmiş, diğer hipotezler ise reddedilmiştir.

Analiz sonuçlarına göre, ilişkisel pazarlama uygulamalarının tamamı göz önüne alındığında, ilgili faaliyeti uygulayan işletmelerin elde ettiği ilişkisel pazarlama faaliyeti sonuçlarının, uygulamayan işletmelere oranla daha yüksek olduğu görülmektedir. Ancak bu uygulamalardan yalnızca dört tanesinde faaliyeti uygulayan ve uygulamayan işletmeler arasındaki farkın bilimsel açıdan anlamlı olacak derecede yüksek olduğu tespit edilmiştir. Ayrıca kardolu çalışan sayısı daha fazla, stajyer sayısı daha az olan ya da hiç olmayan, 1989 yılından önce kurulan acentelerin daha başarılı ilişkisel pazarlama sonuçları elde ettiği görülmektedir.

\section{SONUÇ}

İşletme-tüketici ilişkisinin boyutları ve yeni pazarlama anlayışları, rekabet koşullarının yüksek olduğu seyahat acenteleri pazarında, acenteleri ilişkisel pazarlama uygulamalarına daha fazla değer vermeye ve uygulamaya yönlendirmektedir. Araştırma sonuçlarına göre de acentelerin müşteri memnuniyeti, müşteri değeri, firmaya olan güven gibi müşteri yönlü çıktılarda daha fazla başarı elde edebilmesi ve müşterileriyle uzun süreli ilişkiler geliştirebilmesi, ilişkisel pazarlama faaliyetlerini uygulamalarıyla doğrudan ilişkilidir. Elde edilen bulgulara göre, seyahat acentelerinin büyük bir kısmının ilişkisel pazarlama faaliyetlerini uyguladıkları görülmektedir. Bu durum sektörde ilişkisel pazarlama faaliyetleri ve faydalarına yönelik bir farkındalık bulunduğunu göstermektedir.
Araştırma sonuçlarına göre, seyahat acentelerinde uygulanan ilişkisel pazarlama faaliyetlerinin sonuçları, kullanılan ilişkisel pazarlama uygulamalarının türüne ve şube sahibi olup olmamaya göre farklılaşmaktadır. Acentelerin şubelere sahip olmaları ilişkisel pazarlama faaliyetlerinden elde edilen başarıyı arttırmaktadır. Bu durum, şubesi olan daha büyük işletmelerin daha başarılı ilişkisel pazarlama faaliyetleri yaptıklarını göstermektedir.

İlişkisel pazarlama faaliyetlerinde doğrudan müşteri ve çalışanlara yönelik olanlar, ilişkisel pazarlamadan elde edilen sonuçlarda farklılık yaratmaktadır. Müşteriyi tanıma ve müşteriyle etkileşim kurma faaliyetleri uygulayan acentelerin sağladıkları faydaların, bu faaliyetleri uygulamayan acentelere göre bir hayli yüksek olduğu ortaya konmuştur. Müşterinin işletme tarafından tanınması, müşteri ve işletme arasında daha yakın ve samimi iletişim kurulması, işletmeyi başarılı kılacak kritik unsurlar olarak ön plana çıkmaktadır. Bununla birlikte çalışanlarına müşteri iliş̧ileri eğitimi veren ve çalışanlarının memnuniyetini sağlayan acentelerin, ilişkisel pazarlama uygulamalarından elde ettikleri sonuçlar, bu yaklaşım ve uygulamalara sahip olmayan acentelere göre farklılaşmaktadır. Dış müşteri memnuniyetinin oluşmasında etkin faktörlerden biri de iç müşteri yani çalışan memnuniyetidir. Çalışanların memnuniyeti artırılarak, müşteri ilişkileri yönlü eğitimle dış müşterilerin memnuniyetinin sağlanması amaçlanmaktadır. Bu doğrultuda, araştırmada elde edilen sonuçların da bu varsayımı desteklediği ve çalışan memnuniyetini sağlayarak müşteri memnuniyetine yönelik ilişkisel pazarlama uygulamaları yapan işletmelerin daha başarılı sonuçlar elde ettiği tespit edilmiştir.

Alan araştırmasından elde edilen bu sonuçlar ve ilgili literatür bir arada değerlendirildiğinde; tüm ilişkisel pazarlama faaliyetlerinin kullanılmasının elde edilen sonuçlar üzerinde etkileri olduğu ancak bazılarının işletme yararına fark yaratan sonuçlar ortaya koyabileceği söylenebilir. Dolayısıyla, sektörde faaliyet gösteren işletmelere tüm ilişkisel pazarlama uygulamalarına önem vermelerinin yanında özellikle müşteriyi tanıma, müşteriyle etkileşim kurma, çalışanlara müşteri ilişkileri yönlü eğitim verme ve çalışan memnuniyetini sağlama faaliyetlerinde daha fazla ve farklı uygulamalar yapmaları önerilebilir.

Araştırma neticesinde ortaya çıkan sonuçlar, literatürde ilişkisel pazarlamanın hizmet sektöründeki etkisini araştıran çalışmalardan Karaca (2010), Karakaş vd. (2007) ile marina işletmeciliğinde ilişkisel pazarlama uygulamalarının tekrar satın alma niyeti, tavsiye etme niyeti ve memnuniyet üzerindeki etkisini araştıran çalışmalardan Arı (2013) çalışmalarının sonuç̧larıyla örtüşmektedir. 
Bu çalışmanın benzer alanda yapılacak çalışmalarla desteklenmesi kuşkusuz daha genel sonuçlara ulaşılmasını sağlayacaktır. Bu açıdan çalışmanın değişik coğrafi bölgelerde diğer acente tiplerini de kapsayacak şekilde genişletilmesi ve belki de ilişkisel pazarlama uygulamalarının acentelerce sunulan farkI faaliyetlere göre sınıflandırılarak ele alınması konunun çeşitli boyutlardan değerlendirilmesi açısından faydalı olacaktır. 


\section{KAYNAKLAR}

Arlı, E. (2013) "Marina İşletmeciliğinde İlişkisel Pazarlama Uygulamalarının Tekrar Satın Alma Niyeti, Tavsiye Etme Niyeti ve Memnuniyet Üzerindeki Etkisi" Anadolu Üniversitesi Sosyal Bilimler Dergisi, 13(1):61-76.

Bender, P.U. ve George, T. (2000) Power Marketing, çev. Nurten Akan, Ankara, MediaCat Yayınları.

Cheng, C.F. ve Ai-Hsuan, L. (2011) "The Influences of Relationship Marketing Strategy And Transaction Cost On Customer Satisfaction, Perceived Risk, And Customer Loyalty" African Journal Of Business Management, 5(13):5199- 5209.

Çalışkan, S. (2008) Müşteri İlişsileri Yönetimi, İzmir, Egem Yayınevi.

Doğan, S. ve Selçuk, K. (2007) "Örgütsel Bağlllığın Sağlanmasında Personel Güçlendirmenin Yeri ve Önemi” Erciyes Üniversitesi İIBF Dergisi, 29:37-61.

Erbaşlar, G. (2009) "İşletmelerde İlişki Pazarlaması" Ekonomi Sosyoloji ve Politika Dergisi, 5(2):1-38.

Garbarino, E. ve Johnson, M. (1999) "The Different Roles of Satisfaction, Trust and Commitment in Customer Relationship” Journal of Marketing, 63(2):70-87.

Grönroos, C. (2004) "The Relationship Marketing Process: Communication, Interaction, Dialog, Value" Journal of Business \& Industrial Marketing, 19(2):99-113.

Gummesson, E. (2002) "Relationship Marketing and A New Economy: It's Time For De-Programming" Journal Of Services Marketing, 16(7):585-589.

Gwinner, K.P., Gremler, D.D. ve Bitner, M.J. (1998) "Relational Benefits in Services Industries: The Customer's Perspective" Journal of The Academy of Marketing Sciences, 26(2):101-114.

Hacıefendioğlu, Ş. ve Çolular, N. (2008) "İlişkisel Pazarlamada Güven Unsuru ve Otel İşletmelerinde Uygulama” Kocaeli Üniversitesi Sosyal Bilimler Enstitüsü Dergisi, 16(2):107-126.

Hougaard, S. ve Bjerre, M. (2002) Strategic Relationship Marketing, Denmark, Springer.

İlbani, M., Doğdubay, M. ve Gürsoy, H. (2009) Otel İşletmelerinde İlişkisel Pazarlama Üzerine Karşılaştırmalı Bir Araşırıma” Osmangazi Üniversitesi Sosyal Bilimler Enstitüsü Dergisi, 10(2):117-144.

Karaca, Ş. (2010) "Hizmet Sektöründe İlişki Pazarlaması" Selçuk Üniversitesi Sosyal ve Ekonomik Araştrmalar Dergisi, 13(19):443-458.
Karadeniz, M. (2010) “The Relationship Marketing Approach and Strategies in Retailin Management to constitude Customer and Brand Loyalty" Journal of Naval Sciences and Engineering, 6(1):15-26.

Karakaş, B., Bircan, B. ve Gök, O. (2007) "Hizmet Sektöründe İlişki Pazarlaması: Butik Oteller ve Beş Yıldızlı Oteller Üzerine Karşılaştırmalı Bir Araştırma” Ege Akademik Bakı̧ Dergisi, 7(1):3-18.

Kotler, P. (2011) A'dan Z'ye Pazarlama, Çev. Aslı Kalem Bakkal, İstanbul, MediaCat Yayınları.

Malley L. ve Prothero, A. (2004) "Beyond the Frills of Relationship Marketing" Journal of Business Research, 57(11):1286-1294.

Ndubisi, N.O. (2007) "Relationship Marketing and Customer Loyalty" Marketing Intelligence \& Planning, 25(1):98-106.

O'Malley, L. ve Tynan, C. (2003) "Relationship Marketing" Baker, M.J. (ed.) The Marketing Book, 5th Edition, Oxford, Heinemann.

Onaran B., Bulut, Z.A., ve Özmen, A. (2013) "Müşteri Değerinin, Müşteri Tatmini, Marka Sadakati ve Müssteri İlişkileri Performansı Üzerindeki Etkilerinin İncelenmesine Yönelik Bir Araştırma” Business and Economics Research Journal, 4(2):37-53.

Palmer, A.J. ve Mayer, R. (1996) "Relationship Marketing: A New Paradigm For The Travel and Tourism Sector" Journal of Vacation Marketing, 2(4):326-333.

Parasuraman, A., Berry, L.L. ve Zeithaml, V.A. (1991) "Understanding Customer Expectations of Service" Sloan Management Review, 32(3):39-48.

Reichheld, F.F. (1993) "Loyalty-Based Management", Harvard Business Review, 71:64-73.

Reichheld F.F. ve Sasser, W.E. (1990) "Zero Defections: Quality Comes to Services", Harvard Business Review, September-October, 105-111.

Sarıdaldı, E. ve Şerafettin, S. (2009) "Müşteri Şikâyet Yönetimi Performansının Değerlendirilmesi: TCDD 3. Bölge Müdürlüğ̈̈nde Bir Uygulama” Balıkesir Üniversitesi Sosyal Bilimler Enstitüsü Dergisi, 12(22):110-126.

Saunders, M., Lewis, P. ve Thornhill, A. (2000) Research Methods For Business Students, 2nd. Ed., Prentice Hall, Harlow.

Selvi, M.S. (2007) Illiskisel Pazarlama Stratejiler ve Teknikler, Ankara, Detay Yayıncılık. 
Sin, L.Y.M., Alan, C.B.T., Oliver, H.M.Y., Raymond, P.M.C., Jenny, S.Y.L. ve Lorett, B.Y.L. (2005) "Relationship Marketing Orientation: Scale Development and Cross-cultural Validation" Journal of Business Research, 58(2):185-194.

Skarmeas, D. ve Matthew, J. R. (2008) “Determinants of Relationship Quality in Importer-Exporter Relationships" British Journal of Management, 19:171-184.

Tax, S.S., Brown, S.W. ve Chandrashekaran, M. (1998) "Customer Evaluations of Service Complaint Experiences: Implications for Relationship Marketing" Journal of Marketing, 62(2):60-76.

Thorsten T. H., Kevin, P.G. ve Dwayne, D.G. (2002) "Understanding Relationship Marketing Outcomes; An Integration of Relational Benefits And Relationship Quality” Journal Of Service Research, 4(3):230-247.

Tsiotsou, R. ve Vanessa, R. (2010) "Future Research Directions in Tourism Marketing" Marketing Intelligence \& Planning, 28(4):533-544.
TÜRSAB, (2007) “Seyahat Acenteleri Yönetmeliği”, http://www.tursab.org.tr/dosya/7233/seyahat-acentalariyonetmeligi_7233_4917642.pdf (03.08.2013)

Varinli, İ. (2006) Pazarlamada Yeni Yaklaşımlar, Ankara, Detay Yayıncılık.

Voss, G.B. ve Zannie, G.V. (1997) "Implementing a Relationship Marketing Program: A Case Study and Managerial Implications" The Journal Of Services Marketing, 11(4):278-298.

Yang, Z. ve Robin, T.P. (2004) "Customer Perceived Value, Satisfaction, and Loyalty: The Role of Switching Costs” Psychology \& Marketing, 21(10):799-822.

Yurdakul, M. (2007) "İlişkisel Pazarlama Anlayışında Müşteri Sadakati Olgusunun Ayrıntılı Bir Şekilde Analizi” Dumlupınar Üniversitesi Sosyal Bilimler Dergisi, 17:268-287. 